\title{
Mode of Laying in Fayoumi and White Plymouth in Subtropics at Different Seasons
}

\author{
M. A. Kheireldin, G. A. R. Kamar, A. Darwish and M.M.Ali \\ Animal Production Department, Faculty of Agriculture, Cairo \\ University, Giza, and Assiut University, Assiut, Egypt.
}

\begin{abstract}
16 FArousr and 13 white Plymouth Rock pullets were available 10 during the first year of laying. Fayoumi pullets produced 4322 eggs which comprised $935,668,356,127,53,21$ and 12 clutches of $1,2,3,4,5,6$ and 7 eggs laying cycles respectively. Plymouth pullets produced 2767 eggs having $887,499,191,41,19,6$ and 2 clutches of $1,2,3,4,5,6$ and 7 eggs laying cycles, respectively.

The highest rate of egg production was observed during spring and summer months and the lowest rate was observed in winter and gutumn months. Egg weight, increased during winter and autumn months and decreased during summer and spring months. The larger clutch size was observed during spring and summer months. The first egg in the clutch was laid earlier in the day than the succeeding eggs. The Fayoumi birds laid more number of eggs and longer and larger number of clutches than the Plymouth Rock.
\end{abstract}

The peak of egg yield occurs during winter and spring months when moderate temperature is prevalent, while production is lower during summer and autumn months (Kamar, 1962). The spring egg number represents $37-50 \%$ of the total yearly production (Obeidah, 1956). Nora et al. (1965) reported that the percentage of egg production was low from mid December to the end of February, then reached the maximum from March to mid June. From mid June to August, when the weather was hot, egg production decreased. Under the same environmental conditions, the different breeds produced eggs at different rates and showed different seasonal trends (Samkari, 1962).

After sexual maturity, eggs increase in size, reaching the maximum after 3-5 months from the commencement of laying (Vainikaines, 1960). There is general agreement that egg weight in hot months is lower than in cold ones. There is a steady decline in egg weight from March to June. Afterwards, there is a rise in egg weight during the period from August, to October (Kamar, 1962).

\section{Material and Methods}

16 Fayoumi hens of 6 months of age and 13 white Plymouth Rock hens of 8 months of age were used in this experiment for 21 months. Every breed was housed in separate house with open and shaded yards during the whole period of the experiment. A trapnest was used for each four hens to record individual egg production. The birds were fed a balanced mash diet during 
all the experimental period containing $17.32 \%$ digestible protein and had 65.71 T D N. The clutch size was determined by the number of successive days on which one egg was laid or a group of eggs were laid successively forming a one laying cycle. The monthly mean clutch number of each breed was determined by dividing the total number of clutches on the number of birds of the breed. The monthly clutch size of each breed was determined by dividing the monthly clutch number on mean clutch number.

\section{Results and Discussion}

During the whole experimental period the Fayoumi breed laid larger" number of eggs associated with longer and larger number of clutches than the white Plymouth Rock. An exception to that was the clutch number during April and December and clutch size during september in the plymouth Rock. In Fayoumi, the average monthly egg number, clutch number and clutch size were $13.86,6.96$ and 2.00 eggs respectively. While with the Wite plymouth Rock it was $10.09,5.99$ and 1.70 eggs respectively (Table 1). The differences between breeds in egg number and clutch size were highly significant, but the differences between breeds in clutch number were significant (Table 2). This may be due to the fact that the Fayoumi is more adapted to Egyptian conditions than the Plymouth Rock.

In both breeds the high rates of egg production were observed during spring (March, April and May) and summer months (June, July and August). Meanwhile, the low rates occurred during winter (December, January and February) and autumn (September, October and November). The highest egg number in the Fayoumi and the Plymouth Rock was observed during March, being 25.8 and 176 . eggs respectively. On the other hand, the lowest rates ef egg production took place during October with corresponding values of 8.04 and 7.00 eggs for the Fayoumi and White plymouth Rock, respectively. In Fayoumi, the longest clutch size was observed during February with an average of 2.83 eggs and the smallest clutch size was during December with an average of 1.46 eggs. Also, in the plymouth Rock the longest clutch size was observed during February $(2.39 \mathrm{eggs})$ and the smallest clutch was observed during December (1.00 eggs).

Analysis of variances (Table 2) showed highly significant differences (P 0.01 ) between months in egg number and clutch size. The differences between months in clutch number were significant (P 0.05).

The increase in hr of daylength during spring and summer had a favourable influence on egg production, causing the observed increase in egg number and clutch size. Besides, the decrease of daylength during winter and autumn caused the decrease in the rate of egg production during this period. Similar findings were reported by Obeidaha (1956) and Kamar (1962). Moreover, such results indicated that clutch size increased during the winter and spring months and decreased during summer and autumn months. The only exception from this trend was the low egg number and clutch number during May which may be due to the Kamasien winds (sort.

Egypt. J. Anim. Prod., 15, No. 1 (1975) 
TABLE 1. Monthly variations in egg number, clutch pumber and size and egg weight in the Fayoumi and the White Plymouth Rock breeds.

\begin{tabular}{|c|c|c|c|c|c|c|c|c|}
\hline \multirow[b]{2}{*}{ Months } & \multicolumn{4}{|c|}{ Fayoumi } & \multicolumn{4}{|c|}{ Plymouth Rock } \\
\hline & $\begin{array}{c}\text { Egg } \\
\text { number }\end{array}$ & $\begin{array}{l}\text { Clutch } \\
\text { number }\end{array}$ & $\begin{array}{l}\text { Clutch } \\
\text { size }\end{array}$ & $\begin{array}{l}\text { Egg } \\
\text { weight } \\
\text { (g) }\end{array}$ & $\begin{array}{c}\text { Egg } \\
\text { number }\end{array}$ & $\begin{array}{l}\text { Clutch } \\
\text { number }\end{array}$ & $\begin{array}{c}\text { Clutch } \\
\text { size }\end{array}$ & $\begin{array}{l}\text { Egg } \\
\text { weight. } \\
\text { (g) }\end{array}$ \\
\hline Januasy. . & 15.85 & 6.85 & 2.31 & 47.33 & 6.83 & 3.26 & 2.10 & 54.22 \\
\hline February & 14.58 & 5.15 & 2.83 & 48.07 & 10.70 & 4.47 & 2.39 & 54.57 \\
\hline March .. & 21.58 & 7.81 & 2.76 & 47.66 & 17.65 & 7.74 & 2.28 & 53.16 \\
\hline April . . & 17.08 & 7.07 & 2.42 & 45.60 & 14.70 & 8.26 & 1.78 & 53.78 \\
\hline May... & 12.73 & 5.62 & 2.27 & 44.24 & 7.96 & 4.52 & 1.76 & 52.93 \\
\hline June, ... & 15.89 & 9.85 & 1.61 & 45.42 & 8.96 & 6.17 & 1.45 & 49.28 \\
\hline July . . & 15.15 & 7.46 & 2.03 & 44.59 & 10.83 & 6.83 & 1.59 & 49.28 \\
\hline August . . & 15.96 & 8.62 & 1.85 & 46.01 & 12.44 & 7.26 & 1.71 & 50.99 \\
\hline September & 8.04 & 5.35 & 1.50 & 46.41 & 7.00 & 5.00 & 1.40 & 5659 \\
\hline October. . & 8.04 & 5.35 & 1.50 & 46.41 & 7.00 & 5.00 & 1.40 & 56.59 \\
\hline November . & 8.96 & 5.85 & 1.53 & 46.88 & 7.38 & 5.04 & 1.46 & 59.86 \\
\hline December. & 8.96 & 6.12 & 1.46 & 47.70 & 7.13 & 7.13 & 1.00 & 57.78 \\
\hline Average & 13.86 & 6.96 & 2.00 & 46.30 & 10.09 & 5.99 & 1.70 & 53.63 \\
\hline
\end{tabular}

TABLE 2. F. ralues for egg weight, egg number, clutch number and size as affected by different months in the Fayoumi and the Plymouth Rock.

\begin{tabular}{l|r|r|r|r}
\hline Sources of variations & Egg weight & Egg number & Clutch number & Clutch size \\
\hline Between months.... & 2.3097 & $9.0301 * *$ & $4.9651 *$ & $14.8314 * *$ \\
Between breeds .... & $27.0115^{* *}$ & $31.2622 * *$ & $2.8708 *$ & $20.8045^{* *}$ \\
\hline
\end{tabular}

Significant at 0.05 leve

** Significant at 0.01 level 


\begin{tabular}{|c|c|c|c|c|c|c|c|c|c|c|c|c|c|c|c|}
\hline & 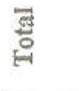 & $\approx$ & $\underset{\delta}{\infty}$ & 을 & $\widehat{\cong}$ & $\tilde{n}$ & $\vec{\sim}$ & 工 & $\underset{\infty}{\infty}$ & ฉे & 5 & $\overrightarrow{7}$ & $\stackrel{a}{-}$ & 0 & $N$ \\
\hline \multirow{12}{*}{ 营 } & 它芯 & ๙ู & $\overrightarrow{0}$ & 0 & 1 & 1 & 1 & 1 & $\stackrel{8}{0}$ & 1 & 1 & 1 & 1 & 1 & 1 \\
\hline & है & 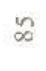 & 8 & 1 & $n$ & | & 1 & 1 & \& & $\stackrel{8}{\circ}$ & 1 & I & | & 1 & 1 \\
\hline & 它蚝 & 2 & $\hat{\therefore}$ & + & $m$ & 1 & 1 & 1 & $\approx$ & $\underset{\infty}{\infty}$ & 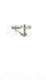 & 1 & 1 & | & 1 \\
\hline & 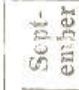 & $\widehat{\simeq}$ & $\bar{\sigma}$ & O & $M$ & 1 & 1 & 1 & $\infty$ & q & 8 & $m$ & - & 1 & 1 \\
\hline & $\begin{array}{l}\text { 菏 } \\
\text { 喝 } \\
\ddot{z}\end{array}$ & 8 & 8ิ & 움 & $r$ & - & 1 & | & $\stackrel{\infty}{\sim}$ & 5 & $\stackrel{\infty}{\sim}$ & 1 & $\nabla$ & 1 & 1 \\
\hline & 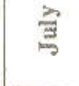 & $\hat{6}$ & $\stackrel{\infty}{2}$ & 웅 & 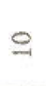 & $m$ & 1 & 1 & $\triangleright$ & in & $\stackrel{\circ}{-1}$ & $N$ & - & - & 1 \\
\hline & 苟 & I & \pm & 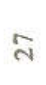 & $n$ & $N$ & 1 & 1 & 홍 & $\stackrel{\circ}{N}$ & $\stackrel{ }{\sim}$ & $m$ & - & - & 1 \\
\hline & 㞼 & i) & 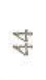 & $\stackrel{\infty}{\infty}$ & 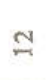 & N & $m$ & - & $g$ & ల్ల & \pm & $n$ & 1 & 1 & 1 \\
\hline & 总 & 8 & $\mathscr{q}$ & $\stackrel{\circ}{4}$ & $=$ & 6 & $n$ & $\sim$ & $\stackrel{⿱}{2}$ & $\infty$ & 요 & $m$ & $\psi$ & $\Rightarrow$ & 1 \\
\hline & है류 & 8 & 옹 & $\widehat{\sigma}$ & $\approx$ & $\Xi$ & $m$ & 6 & F & 98 & कै & $=$ & $m$ & $\mathrm{~N}$ & 1 \\
\hline & 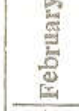 & $\stackrel{\infty}{N}$ & న్ల & $m$ & $\stackrel{ \pm}{\sim}$ & $\Rightarrow$ & $n$ & -1 & 'ㅇ & ๙ี & స్ & $\infty$ & $m$ & -1 & -1 \\
\hline & 胥 & ฉి & 요 & ₹ & 2 & $=$ & - & $N$ & $\tilde{N}$ & $\stackrel{\infty}{\sim}$ & $\Rightarrow$ & 0 & $N$ & I & - \\
\hline & 造 & -1 & $N$ & $m$ & + & $n$ & 6 & $\sim$ & - & $N$ & $m$ & $\phi$ & $n$ & 6 & $r$ \\
\hline & 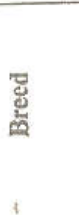 & & & & 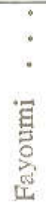 & & & & & & & 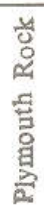 & & & \\
\hline
\end{tabular}

Egypt. J. Anim. Prod., 15, No. 1 (1975) 


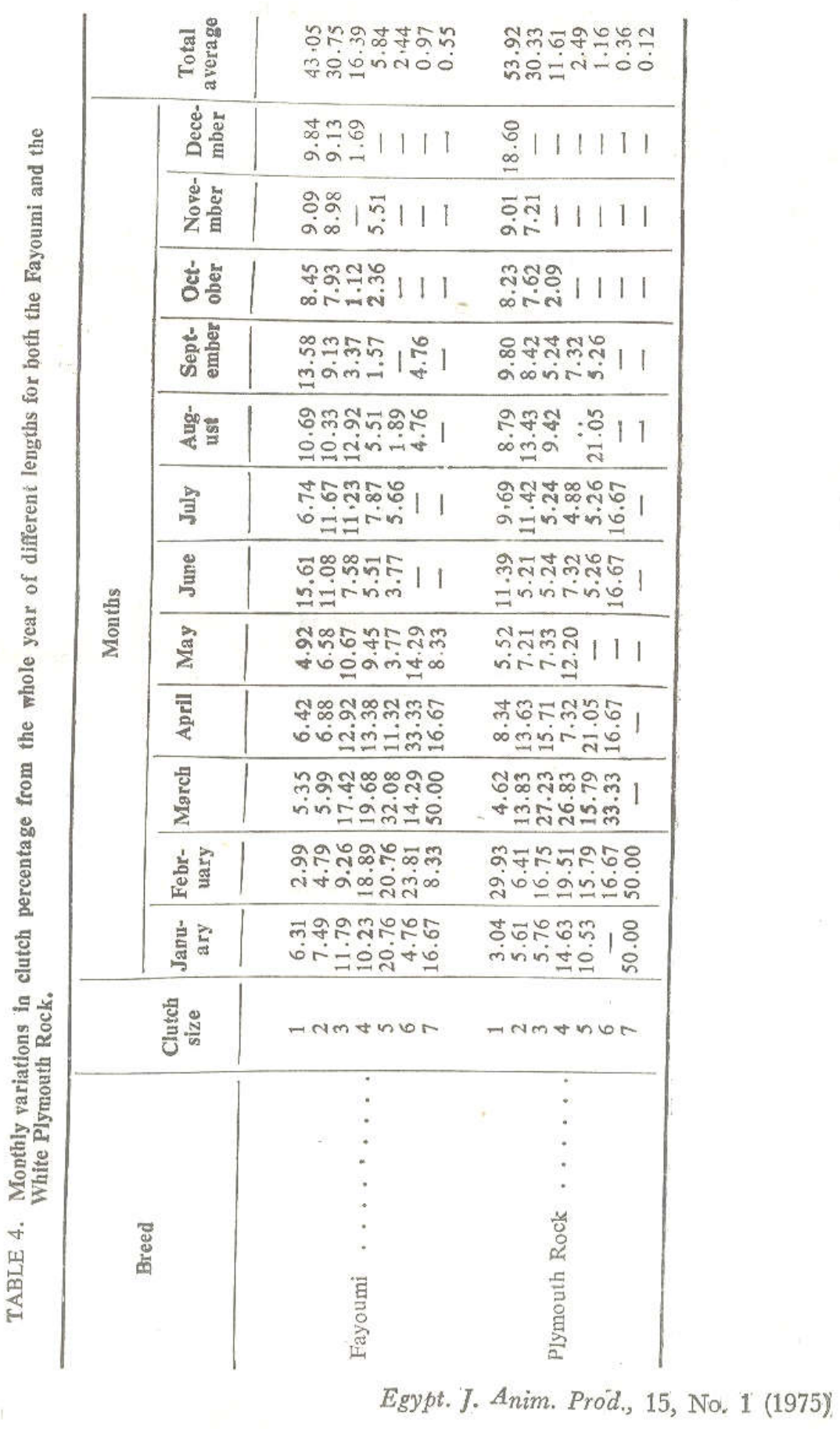


of hot sand storms). The egg number decreased from 17.08 eggs during April to 12.73 eggs during May in the Fayoumi and from 14.70 eggs during April to 7.96 eggs during May in the plymouth Rock.

It was also found that the decrease in daylength than $13 \mathrm{hr}$ in some autumn and winter months was associated with the decrease of four, five, ix seven egg laying cycles in these months. Meanwhile, the absence of these long clutches during June, July and August (summer) may be due air temperature during summer (Table 3). It can be stated the long days are essential for the that both moderate length of the clutch increased, its percentage from the total clutches decreased (Table 4).

Table 1, shows that the heaviest eggs were laid during winter and autumn decrease in egg number was compensated by the increase in months when the decrease in were produced during hot summer months, a egg size. The lightest eggs were produce differences result is normally observed in the northerificant (Table 2). The increase between months in egg weight were not significant (Table effect on egg forin air temperature during summer months haction in egg weight, of the magnmation. Kamar (1962) found an abrupt hens to increased environmental temitude of perature.

\section{References}

Kamar, G.A.R. (1962) Some environmentaland physiological factors that production in the subtropics. Philippines $J$. Anim.

Obeidah, A.M.A. (1956) A comparative study of some of egg recor breeding value of poultry. M.Sc. Thesis, Carro University.

Nora, M.A. Mordenti, and Monetti, P.G. (1965) The effect of temperature on ital. Sci. Vet.t tion and fo $18,248$.

Samkari, M.K. (1962) A comparative study of some economical characters in Rhode Island Red, Faysumi, Balcdi and their crosses. M. Sc, Thesis Cairo Univ. Fac. Agrie. Vainikainen, V. (1950) The development of tive weight of h
the laying season. Matolour ja Koltoim 11, 24.

Egypt. J. Anim. Prod., 15, No. 1 (1975) 


$$
\begin{aligned}
& \text { طريقة وضع البيض فى اللجاج الفيومى } \\
& \text { 'جمال الدين قهر ، متحود خي الدين ، عبد المجيد دوريش ومصطفى على }
\end{aligned}
$$

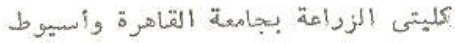

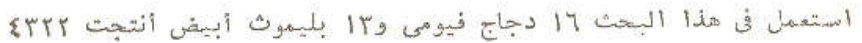

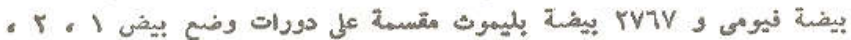

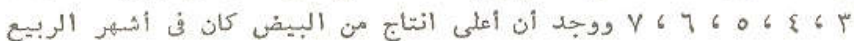

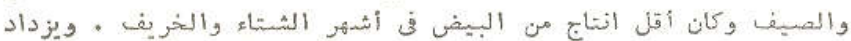

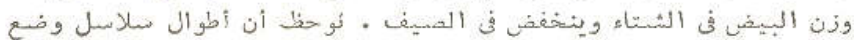

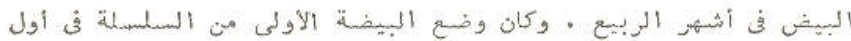

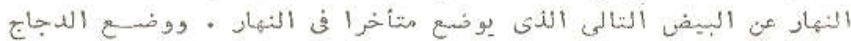

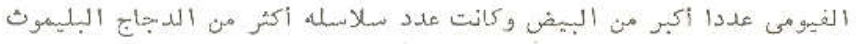

$$
\text { الأبيضن الفيو نمى }
$$

